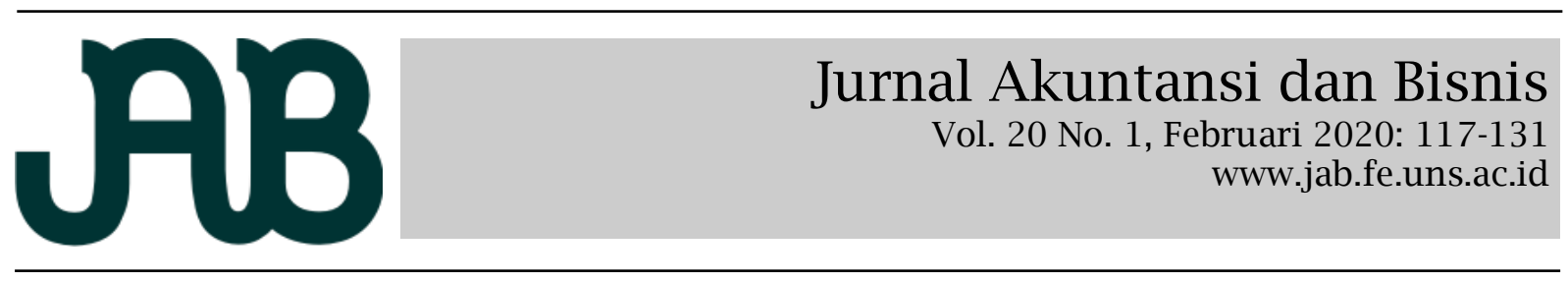

\title{
ENTERPRISE ARCHITECTURE MODELING OF FINANCIAL INFORMATION SYSTEMS USING ADAPTED ZACHMAN FRAMEWORK
}

\author{
FARIDIAH AGHADIATI FAJRI (faridiahagha@ugm.ac.id) \\ FAIZ ZAMZAMI \\ HILDA OCTAVANA SIREGAR
}

Accounting, Vocational School, Universitas Gadjah Mada, Indonesia

\begin{abstract}
As an emerging country, The Regional Public Service Agency in Indonesia is currently allowed to manage their finances independently. The transformation into a regional public service entity was followed by several consequences, one of which was related to the reporting process to the readiness to be audited by the government external auditor. Information technology is able to facilitate the preparation of financial statements, however, the design of information systems in a bureaucratic environment requires a specific subscription. This design requires defining the architecture of information use. This research resulted in a blueprint with an Enterprise Architecture Planning (EAP) approach as the basis for designing financial information systems. In addition, this research also used the Software Process Improvement (SPI) approach to improve the success of information systems. Information technology becomes a vital requirement considering many demands and obligations of BLUDs in terms of financial reporting and performance. The existence of this Enterprise Architecture Model aims as a bridge between organizational goals and information technology to meet these requirements. The results of this study are blueprints of financial software design, especially for BLUD in the health sector in Indonesia.
\end{abstract}

Keywords: Enterprise Architecture Modeling, Information System Blueprint, Regional Public Service Agency, Software Process Improvement

\begin{abstract}
Sebagai negara berkembang, Badan Layanan Umum Daerah di Indonesia saat ini diizinkan untuk mengelola keuangan mereka secara mandiri. Transformasi menjadi entitas layanan publik daerah diikuti oleh beberapa konsekuensi, salah satunya terkait proses pelaporan hingga kesiapan untuk diaudit oleh auditor eksternal pemerintah. Teknologi informasi mampu memfasilitasi penyusunan laporan keuangan, namun demikian, desain sistem informasi dalam lingkungan birokrasi memerlukan perlakuan khusus. Desain ini membutuhkan pendefinisian arsitektur penggunaan informasi. Penelitian ini menghasilkan cetak biru dengan pendekatan Enterprise Architecture Planning (EAP) sebagai dasar untuk merancang sistem informasi keuangan. Selain itu, penelitian ini juga menggunakan pendekatan Software Process Improvement (SPI) untuk meningkatkan keberhasilan sistem informasi. Teknologi informasi menjadi kebutuhan vital mengingat banyak tuntutan dan kewajiban BLUD dalam hal pencatatan, pelaporan hingga pertanggungjelasan kinerja keuangan. Keberadaan Enterprise Architecture Modeling ini bertujuan sebagai jembatan antara tujuan organisasi dan teknologi informasi untuk memenuhi kebutuhan ini. Hasil penelitian ini adalah cetak biru desain perangkat lunak keuangan, terutama untuk BLUD di sektor kesehatan di Indonesia.

Kata kunci: Pemodelan Arsitektur Perusahaan, Cetak Biru Sistem Informasi, Badan Layanan Publik Regional, Peningkatan Proses Pengembangan Perangkat Lunak
\end{abstract}

\section{INTRODUCTION}

Regional Public Service Agency, known as Badan Layanan Umum (BLUD) requires information systems to support operational activities. The existence of an information system is also able to simplify bureaucratic because the system run in real -time so that waiting times and bottle-neck problem that often occurs can be overcome. However, the implementation of the system often encounters obstacles. There are many studies on the success of information systems discussed the complexity of implementing information 
systems. The growing need for integration of Information and Communication Technology (ICT) applications has led to increased complexity in the Information Systems Development Project (ISDP). These ICT needs involve complexities that extend beyond the ability of traditional design approaches so that new approaches are needed to design complex ICT systems (Hanseth \& Lyytinen, 2010). Conceptual modeling has always been a challenge in modeling the unique conditions of an entity into an information system. Although a number of techniques and approaches have been proposed, the challenge remains as to how to develop proper and accurate models that facilitate the entity's uniqueness (Kaul et al., 2017). Therefore, it is important to develop a valid and reliable framework. Technical complexity and task dependency have a contingent effect suggesting the need for technology training, such as user certification, and for consideration regarding personnel assignments (Sharma \& Yetton, 2007). Increased participation of top managers in supporting complex new SI projects can be achieved by activating communication procedures (Bueno \& Gallego, 2017). User involvement has been shown to significantly increase the success of information systems implementation in organizations (Eldenburg et al., 2010). Besides, the use of technology is capable to overcome organizational problems.

When Community Health Centers are known as Pusat Kesehatan Masyarakat (Puskesmas) changes form to a public service agency, several obligations had to be achieved. In addition to always providing excellent service to the community, BLUD also has to more efficient so that it could develop and be independent. BLUDs are expected to have excellent performance and maintain accountability as part of the government. Fajri, et al. (2018) presented the use of information systems can increase local government accountability which is moderated by organizational commitment. Organizational commitment reflected in users can increase the existing system's usage thus improve performance and accountability. When the subordinate unit or Satuan Kerja (SatKer) has decided to change its form to BLUD, it means that the SatKer has high organizational commitment. This guide was developed for the BLUD with the assumption that the rules and hierarchy of government remain inherent, but in the discussion, it is more directed towards entities that are oriented towards excellent service and performance towards independence.

Ministerial Regulation No 61 of 2007 concerning Technical Guidelines for Financial Management BLUD, clause 116 stated that BLUD conducts accounting and financial reports in accordance with financial accounting standards issued by the Indonesian accounting profession association in this case Financial Accounting Standards. This report can disclose business management practices. However, at the end of 2018, there is the latest Ministerial Regulation. Ministerial Regulation No 79 of 2018 concerning BLUD clause 99 stated that the reporting and accountability of BLUDs are prepared based on government accounting standards.

This standard alteration requires the BLUD to prepare both 2 versions of financial statements. The first version, financial statements with financial accounting standards to disclose the running business processes. The second version is used to simplify the consolidation process and the audit process by government external auditors. The process of preparing financial statements will be easier with information systems usage. Government Regulation No. 56 of 2005 concerning Regional Financial Information Systems explained that local governments should use and develop information technology in terms of managing finances and disclose financial information to the society. BLUD follows the regulation which states that its financial reports must be submitted and consolidated at the level of the District Health Office. This regulation sets the financial reporting that must be prepared so that this design can be used by BLUDs in other districts.

Information systems or software 
development is an investment that requires not only expensive costs but also personnel effort and time allocation. There were many cases of implementation of information systems that failed because of the IT Productivity Paradox. Brynjolfsson \& Hitt (1998) shown the most failed information technology implementation projects are caused by overbudget, installation delay, lack of expected features or functions, or even failure in the form of implementation cancellation. Compliance with institutional reporting is easier. Also, the information system enables the data element validation which significantly increases the data accuracy (Kaushik \& Raman, 2014). The process of tracking a balance is made easier through an online system. Periodic reporting can also be made more practical and clearly identified.

Utomo (2014) has proposed the Enterprise Architecture Planning (EAP) as a framework used to build a model or blueprint containing technology contrivance for a specific enterprise. In private entities, the benefits of EA are defined by the gained profit. In the case of a government or public sector, the performance is not strictly measured by financial indicators. There are several measurements, such as service integration, customer satisfaction, transparency and accountability, service improvement, performance agility, and speed of decision making. Zachman's Framework offers solutions for complexity and uncertainty (Lapalme et al., 2016). Thus, to cope with the complexity of the health sector business processes and uncertainty over the agility of regulatory changes, empowerment is the key to building adaptive capacity. This framework is often used in developing systems in private entities. This study adopts it in the context of developing systems in public entities.

EA is a bridge between organizational strategy and information systems. In this context, the bureaucratic environment requires a special approach. Many works of literature examine the Software Process Improvement (SPI) approach in SMEs software development. This study compares the SPI literature that reports hinder factors of the SPI success so that it can be managed better. It also showed practitioners' confirmation of the main problems that de-motivated them, such as the rejection of change, lack of evidence, forced SPI initiatives, resource constraints and commercial pressures. Although the SPI approach provides many benefits, several de-motivated factors must be considered. The users as a part of society that is currently widely called "digital society" (Hossain \& Quaddus, 2012). However, this digital society cannot develop if users do not use IS continuous. Users' expectations which are in line with the system performance resulted in assessments or evaluations that build the satisfaction and intentions of sustainability to use them.

Ministerial Regulation No 31 of 2019, Community Health Centers has the chance to develop their information system. This challenge can be a trigger to develop information systems that can leverage performance. As a first step, the Zachman Enterprise Architecture Framework is used to guide and structure the discussion. This paper uses the two highest perspectives in this framework. Second, this study adopts software process improvement that is adjusted to the bureaucratic conditions inherent in this health service. This study combines the EAP of Zachman's Framework v3.0 model with the software process improvement approach. The discussion will continue with the adjustment of Software Process Improvement (SPI) that is suitable for BLUD.

\section{LITERATURE REVIEW}

\section{Software Process Improvement (SPI)}

Software development requires a relatively large cost. Software Process Improvement (SPI) is the main strategy used by software developers to reduce cost or to increase designing speed and quality. SPI is closely related to users, environmental, social, and organizational factors. The motivation for all related elements must be managed properly so that the SPI can run optimally (Espinosa-curiel \& Rodríguez-jacobo, 2016).

Goldenson, et al. (1995) surveyed process improvement software to 
understand its benefits and the influencing factors. Factors related to SPI's success efforts include: 1) Employees who involved in SPI are persons who are respected or occupy high-level positions so that other involved staff is willing to cooperate better. The influencer in the organization can direct the people to follow the plan thus they kindly help the process. 2) Administration Staff must be more involved in the SPI process, especially in the mapping process because of the administration process related to the data and information input. Moreover, they are the key person who best understands the needs of information technology. Although administrative staff sometimes have difficulty conveying their needs. Neurolinguistic Programming is an approach related to communication and the existence of subjective experiences to understand and motivate others (Singh \& Abraham, 2008). So, the role of the systems analyst is needed to understand the needs at the administrative level. 3) The schedule and workload have been re-managed so that the involved staff is not burdened by additional activities related to the development of this system. This is necessary to prevent staff from being forced to work because there is no compensation for this additional activity. 4) The development goals and objectives have been well explained and understood by those who directly involved in the process and the users. This understanding can increase the desire to help achieve common goals. Hameed, et al. (2012) state that organizational readiness is the most important factor in the process of adopting new technologies.

There are several other factors related to SPI that have been less successful, including: 1) There is an employee with a "Turf Guarding" behavior, where the employee feels threatened thereby creating boundaries to protect his area. Hwang, et al. (2018) examined that staff may feel stressed with new technology. A personal approach can be taken to solve this problem. Company policies must also be discussed properly so that solutions are found for parties affected by SPI. 2) The existence of pessimism that arises from the experience from the failure of previous information technology. This must be addressed immediately by strengthening internal objectives thus all elements of the organization can fully support the SPI's activities. 3) There is a staff perception that this additional work interferes with their daily activities. If this perception is not better encounter and spreads to other staff, it will hamper the development process.

The process starts with setting goals. Then the measurement feasibility analysis is carried out. If not feasible, it will be returned to the initial goal-setting (Bibi et al., 2010). Software Process Improvement (SPI) is a series of activities that go through several stages and involve many parties. Support and willingness from personnel in the organization play an important role until the goals, implementation schedule, and job allocation have to be well understood.

\section{The Productivity Paradox}

Brynjolfsson (1998) has proposed that the implementation of information technology can produce a dual effect known as the IT Productivity Paradox. Positive results expected by organizations when implementing information technology include cost efficiency, increased production capacity, reduced waiting time, bottleneck completion, and increased customer satisfaction. Utilization of IT as an information manager which is capable of overcoming company problems. Organizations with well-managed information can quickly respond to changes in demand from customers so that the effects in the supply chain can be handled optimally.

The worst impact that an organization might experience is a system failure. The incompatibility of information technology with the condition of the company may cause failure. It is due to an initial analysis process that unappropriated. Obstacles occur when the implemented system is a ready-made system. Adjustment becomes difficult to fulfill the needs of the organization. Other failures are caused by other fac- 
tors, such as over budget, delay in installation, or lack of features. The properly planned process can reduce the possibility of information system failure. Previous empirical research has proven that the existence of information technology can have a positive impact on organizations. Research Ii et al., (2019) shows that IT development not only has a positive impact on internal companies but also attracts investors. Investors see IT development as a potential for growth and expansion. Tian $\& \mathrm{Xu}$ (2015) have conducted research on the application of information technology to an organization's risk level and show the results that the existence of ERP can significantly reduce the company risk. Research Dos, et al. (2017) regarding the value of IT's contribution to market value is carried out to see investors' profits from the application of IT in banking companies.

\section{Enterprise Architecture}

The organization expects that the information technology can support and be inline with their goals, Enterprise Architecture (EA) becomes a solution as a bridge (Sessions, 2015). In the beginning, this field was initiated to be a solution to the system complexity and poor business alignment. EA should be well designed thus it increases coherence with management so that technology leads to alignment, agility, and assurance in organizations' goals. EA is a depiction of high-level management's view of business processes and information systems in the form of reciprocal relationships. EA design becomes the process of translating principles, abilities, and goals in a strategy into the system (Saha, 2010; Tamm et al., 2011). This system will help the company achieve its goals. In addition, EA is also a map that will guide the company to achieve its long-term goals.

Nowadays, improvement in service delivery and overall organizational performance becomes the main driver. The EA design can transform the company's big plans into operational details, thus EA can be called a blueprint for business processes and organizational systems. Zachman Framework is a logical structure for identifying, classifying, and organizing representations of an organization (Zachman, 2016). This framework can be useful for both manual systems and automated systems. This framework presents The Enterprise Ontology using a matrix with four combined structures. The structure includes perspective, classification, enterprise main process, and model names. Zachman Framework V.3, this latest version uses six perspectives, namely planners, owners, architects, engineers, technicians, and users' perspectives. Classification is discussed by answering several items, namely what material is used (what), how the process works (how), where components interact with each other (where), who does (who), when (when), and why (why) the process it was done. Then, the matrix is completed with the main functions of the organization and determines the running model.

\section{Technical Guidelines for Public Service Bodies}

The Ministry of Home Affairs Regulation No. 61 of 2007 concerning Technical Guidelines for Financial Management of Regional Public Service Agencies in article 16 regulates the BLUD' financial statements. The main financial statements are prepared based on governments accounting standards consisting of: Budget Realization Report, Balance Sheet, Operational Reports, Cash Flow Statement, and Notes to the Financial Statements

However, the same clause also stated that BLUDs must present the operational and balance sheet projections based on accounting standards issued by the Indonesian accounting profession association. It is also shown in article 116 regarding accounting, reporting, and accountability indicating that the BLUD conducts accounting and prepares financial reports based on financial accounting standards to disclose well business management. The reporting uses accrual basis in the recognition of revenue, expenses, assets, liabilities, and equity funds. Whereas for consolidation government accounting standards are applied (article 121).

The Ministry of Home Affairs 
Regulation No. 79 of 2018 concerning Regional Public Service Agencies was issued based on the consideration that Permendagri No. 61 of 2007 because it was not in accordance with the dynamics of the development of laws and regulations concerning BLUD. This regulation no longer addresses the need to prepare financial statements using financial accounting standards issued by the Indonesian accounting profession association. However, in article 99 paragraph 6 the BLUD must prepare a performance report containing information on the BLUD' achievement. Information technology helps BLUD meet complex financial reporting obligations and readiness to undergo the audit process.

\section{RESEARCH METHODS}

Research on information technology design is mostly carried out in the private sector. This gap is caused by existing software provided by the government. Different conditions with BLUDs that do not have a specific financial information system that meets the needs of the BLUD. Zachman's framework (Lapalme et al., 2016) adoption will be conducted at two levels of perspective, namely the planner's perspective and the owner's perspective. This research designs a blueprint that serves as a guide for information systems developers, BLUDs, and even the government. Currently, Community Health Centers have flexibility in the use of their information systems. Thus, the method used includes an explanation of the Enterprise Architecture (EA) approach used and the identification of EA domains. Besides, this research develops a Software Process Improvement (SPI) framework that is suitable for use in BLUDs when building information systems.

BLUD have the flexibility to manage their assets so BLUD has a chance to develop or buy independently. However, nowadays, there are still many BLUDs that have not an adequate profit so the ability to improve their information technology is still limited. This research will conduct software design accompanied by the Software Process Improvement (SPI) approach so that the success rate of the system be-

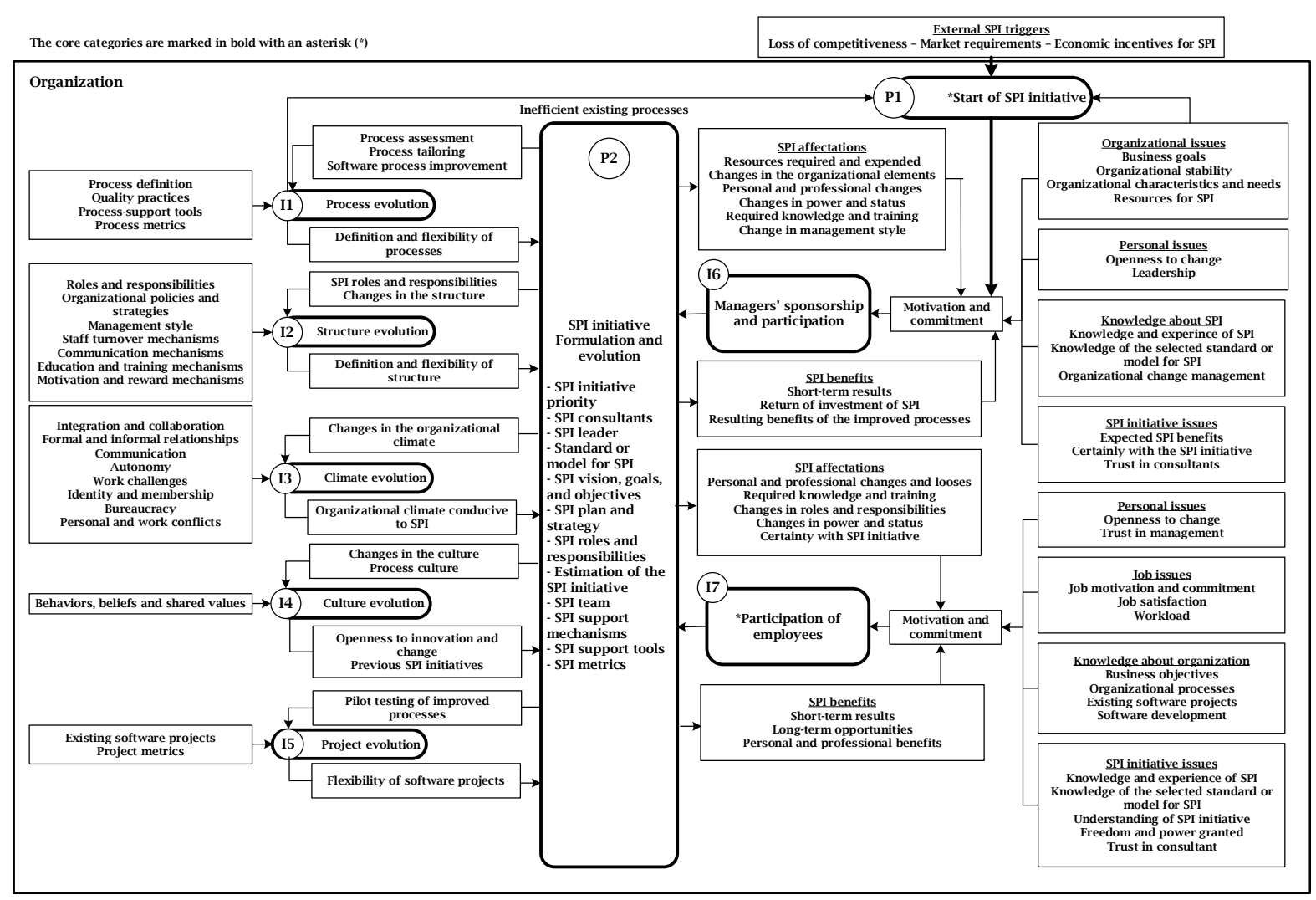

Figure 1.

Software Process Improvement (SPI)

Source: Espinosa-curiel \& Rodríguez-jacobo (2016) 
comes higher. Capability Maturity Model Integration (CMMI) is a framework that drives an organization's business performance (CMMI Institute, 2003). SPI models such as CMM and CMMI are often overlooked even tough this process must be an initial emphasis (M. Valle et al., 2017). The process of identifying maturity levels using CMMI is the latest framework in Software Process Improvement (SPI). In this stage, the guidance of maturity level test developed to help BLUD understand their current level. Then, Software Process Improvement (SPI) is adjusted by looking at the stages that are relevant to the conditions of the BLUD.

The SPI process to be adjusted is the result of Espinosa-curiel \& Rodríguezjacobo's (2016) research. The existing stages will be carried out entirely, but several sub-stages are adjusted to the conditions of the research object because of the bureaucratic entity's unique characteristics. Figure 1 shown the full model of Software Process Improvement which emphasizes employee participation as core categories. The development of Enterprise Architecture Planning (EAP) in Zachman's Framework which is complemented using the Software Process Improvement (SPI) approach is a novelty development in this research. Proper information system planning with the current state alignment of the organization is able to increase the success of the planned information system.

\section{ANALYSIS AND DISCUSSION}

Enterprise Architecture (EA) is the main strategy carried out as a framework that guides the implementation of egovernment around the globe (Anthopoulos et al., 2010). The EA Model provided benefit through improvements in Organizational Alignment, Information Availability, Resource Complementarity, and Optimization of the Portfolio of Resources that directs EA to organizational benefits (Tamm et al., 2011). These benefits can include lower costs, higher strategic agility, and a more reliable operating platform. BLUD in the health sector is a large organization with a complex IT environment and requires an integration of alignment at the provincial level to get the benefits of EA optimally.

Zachman's model starts the framework from the perspective of the planner about development needs (Iyamu, 2018). At this stage, the planner identifies needs, establishes the scope, development background, and objectives of the entity. The company's business strategy (EBS) shows an entity's focal point and the growth direction (Kang et al., 2010). EBS in private entities is often the responsibility of senior managers while in the context of this paper is a decision produced by the collaboration of the head of the department with the systems analyst. This intense foundation will guide the next stage. In general, BLUDs need information

Table 1.

CMMI Maturity Level

\begin{tabular}{|c|c|c|}
\hline Maturity & Stage & Condition \\
\hline Level 0: Incomplete & Ad hoc and unknown & $\begin{array}{l}\text { The task is often in an unresolved condi- } \\
\text { tion }\end{array}$ \\
\hline Level 1: Initial & $\begin{array}{l}\text { Unpredictable and } \\
\text { reactive }\end{array}$ & $\begin{array}{l}\text { Tasks are completed but often not on } \\
\text { schedule and budget }\end{array}$ \\
\hline Level 2: Managed & $\begin{array}{l}\text { Managed on the project } \\
\text { level }\end{array}$ & $\begin{array}{l}\text { The tasks in the project go through the } \\
\text { planning process, can be measured, and } \\
\text { controlled }\end{array}$ \\
\hline Level 3: Defined & $\begin{array}{l}\text { Proactive, rather than } \\
\text { reactive }\end{array}$ & $\begin{array}{l}\text { The organization has documented stand- } \\
\text { ards regarding work guidance }\end{array}$ \\
\hline $\begin{array}{l}\text { Level 4: Quantita- } \\
\text { tively Managed }\end{array}$ & $\begin{array}{l}\text { Measured and con- } \\
\text { trolled }\end{array}$ & $\begin{array}{l}\text { The organization is supported by quanti- } \\
\text { tative data that supports the achievement } \\
\text { of performance }\end{array}$ \\
\hline Level 5: Optimizing & Stable and flexible & $\begin{array}{l}\text { The organization has focused on continu- } \\
\text { ous improvement with the use of plat- } \\
\text { forms that support agility and innovation }\end{array}$ \\
\hline
\end{tabular}


systems to fulfill their accountability responsibilities for their financial flexibility, while the specific objectives can be determined by each entity later. The owner's perspective in this framework will formulate the concept of business management and establish its conceptual model.

There are several deliverable EAs that are in focus. Environmental conditions must be well understood to build information systems that can adapt to change. The Enterprise's business strategy (EBS) is the result of the formulation of strategic goals and objectives, both short-term and long-term (Kang et al., 2010). Conceptual Principles are designed based on the organization's vision, goals, and objectives which are used as a guide for personnel in the form of rules, regulations, and ethics and can be used as evaluation criteria. Business Information Requirements (BIRs) are the information needed by an entity to carry out its business processes. This need is de- signed to support EBS. Business process integration is carried out to align activities with company rules through interfaces, interactions, and connectivity, both at the horizontal and vertical levels. The Enterprise Value Network (EVN) defines the relationships that occur in business processes, networks, and distribution channels.

Table 2 shows the concept of mapping the EA deliverables and EA domains in the adopted Zachman framework (Iyamu, 2011). The mapping in the table explains how EA was developed with the perspective of Zachman's, the technical domain, as well as recommendations for implementation in the BLUD system development process in the field.

The enterprise architecture domain column shows where the scope of system development takes place. Several domains are directly related to the perspective of the planner and owner. The Enterprise Information Architecture (EIA) provides benefits for organizations that develop compa-

Table 2.

Enterprise Architecture Mapping

\begin{tabular}{|c|c|c|c|}
\hline $\begin{array}{l}\text { Zachman's } \\
\text { Framework }\end{array}$ & $\begin{array}{l}\text { Enterprise Ar- } \\
\text { chitecture De- } \\
\text { liverable }\end{array}$ & $\begin{array}{l}\text { Enterprise } \\
\text { Architecture } \\
\text { Domains } \\
\end{array}$ & Related Activities \\
\hline \multirow{5}{*}{$\begin{array}{c}\text { Executive } \\
\text { Perspective } \\
\text { (Business } \\
\text { Context } \\
\text { Planners) }\end{array}$} & \multirow{2}{*}{$\begin{array}{l}\text { Environmental } \\
\text { Condition }\end{array}$} & EBA & $\begin{array}{l}\text { Consider to the uncertain changing } \\
\text { BLUD's regulations }\end{array}$ \\
\hline & & EIA & Identify the BLUD trends periodically \\
\hline & $\begin{array}{l}\text { Enterprise's } \\
\text { Business } \\
\text { Strategy (EBS) }\end{array}$ & EMG, EBA & $\begin{array}{l}\text { Identify strategies that are consistent } \\
\text { with the goals and objectives of the } \\
\text { BLUD to ensure independence and } \\
\text { sustainability }\end{array}$ \\
\hline & $\begin{array}{l}\text { Business Pro- } \\
\text { cess }\end{array}$ & EIA, EMG & $\begin{array}{l}\text { Carry the different channels of } \\
\text { communication within BLUD } \\
\text { Identify the relationship between }\end{array}$ \\
\hline & $\begin{array}{l}\text { Enterprise Value } \\
\text { Network (EVN) }\end{array}$ & EIA, EMG & $\begin{array}{l}\text { BLUD and the public health office } \\
\text { (Dinkes) in its bureaucratic hierarchy } \\
\text { and with health services in the area }\end{array}$ \\
\hline \multirow{5}{*}{$\begin{array}{c}\text { Business } \\
\text { Management } \\
\text { Perspective } \\
\text { (Business } \\
\text { Concept } \\
\text { Owners) }\end{array}$} & $\begin{array}{l}\text { Business Pro- } \\
\text { cess }\end{array}$ & EMG, EBA & $\begin{array}{l}\text { Define BLUD events and scenarios } \\
\text { about how events are identified, } \\
\text { managed, and documented. }\end{array}$ \\
\hline & $\begin{array}{l}\text { Business } \\
\text { Information }\end{array}$ & EIA & $\begin{array}{l}\text { Identify what information is required } \\
\text { by BLUD and regulation }\end{array}$ \\
\hline & $\begin{array}{l}\text { Requirements } \\
\text { (BIRs) }\end{array}$ & EMG & $\begin{array}{l}\text { Design information relations related } \\
\text { to business logic, processes and } \\
\text { activities that occur at BLUD }\end{array}$ \\
\hline & $\begin{array}{l}\text { Conceptual } \\
\text { Principles }\end{array}$ & EMG, EBA & $\begin{array}{l}\text { Break down the vision, goals, and ob- } \\
\text { jectives in the form of BLUD struc- } \\
\text { ture, rules, regulations, and ethics }\end{array}$ \\
\hline & $\begin{array}{l}\text { Business Pro- } \\
\text { cess Integration }\end{array}$ & EIA & $\begin{array}{l}\text { Identify main processes at BLUD, de- } \\
\text { sign business process integration and } \\
\text { related information }\end{array}$ \\
\hline
\end{tabular}


nies through embedded principles (Iyamu, 2011). This domain includes the principles of information flow, lines of communication, restrictions on authority, and their use in decision making at BLUDs. The Entity Main Goals (EMG) is the scope of system development based on the goals and objectives of the organization. In BLUD this scope is closely related to long-term strategic plans and work programs and activities in the short term. Enterprise Business Architecture (EBA) consists of integrating basic concepts that are transformed into organizational goals. This architecture presents operational and network performance among personnel (Chew \& Gh Dehbokry, 2014; Whittle, 2016). EBA describes the current state, determines the BLUD's strategy and road map.

Various development standards and Software Process Improvement (SPI) models have been made. Capability Maturity Model Integration (CMMI) is one of the latest frameworks that encourage business performance through the development of key organizational capabilities (CMMI Institute, 2003). In the initial stages, the BLUD synchronized daily operations with its objectives. This framework has been developed by Niazi et al. (2005) into 3 components, namely maturity stage dimension, CSF dimension, and assessment dimension First, the board of directors must determine at what level the BLUD's maturity. After deciding on the level, the organization ensures activities that must be carried out. Critical Factor Success (CFS) was developed by Niazi et al., (2005) is an effort to increase the successful implementation of information systems through Software Process Improvement (SPI). The CFS is adjusted and sorted to the BLUD conditions and is summarized in Table 3. Developers and management must try to make the CFS and the activities carried out to the maximum. This research transforms the barriers into critical success factors to positively enhance cognitive.

The existence of the uniqueness and needs of the user organization, EA will be aligned with the Software Process Improvement (SPI). SPI is divided into 2 stages, namely the preparation phase and the implementation phase. The preparatory stage begins with the initiation to develop software. This initiation must have the support and cooperation of the board of directors and management. SPI starts with the basis of motivation and commitment from management and employees. This

Table 3.

Adapted CFS and Its Activities

\begin{tabular}{|c|c|}
\hline CFS & Activities \\
\hline Awareness & $\begin{array}{l}\text { Promotion related to the benefits of SPI to all BLUD personnel } \\
\text { The higher management at BLUD truly understands the needs of devel- } \\
\text { oping this system } \\
\text { Personnel understand the role carried out during the implementation } \\
\text { of SPI } \\
\text { The formation of organizational culture that is in line with SPI }\end{array}$ \\
\hline Staff & Personnel involved show interest and commitment \\
\hline Involvement & $\begin{array}{l}\text { There are task adjustments to avoid work overloads } \\
\text { Timeline planning to avoid time pressure }\end{array}$ \\
\hline Action Team & $\begin{array}{l}\text { The team has been formed from experienced people } \\
\text { There is a mechanism for monitoring team performance } \\
\text { There are regular forums that are used to share knowledge learned by } \\
\text { team members }\end{array}$ \\
\hline Support & Management shows leadership and strong support \\
\hline System & $\begin{array}{l}\text { Management is committed to providing resources and facilities } \\
\text { Management participates in monitoring and evaluation } \\
\text { Management provides training and document literacy } \\
\text { Conflict resolution plan has been prepared }\end{array}$ \\
\hline
\end{tabular}


stage was completed with the SFS component in Table 3. Furthermore, the motivation and commitment entered the SPI Formulation and Evolution area in the form of support and participation. In this stage, organizational issues including goals setting, organizational stability, characteristics, and needs have been constructing motivation and commitment. Moreover, the expected benefit and trust in the project team also contribute. Those are shown as managerial involvement and commitment. Several main factors are openness and trust in management. BLUD as an expanded subordinated unit of the government create a new perspective and affective of the staff. They are more likely to internalize the organization's goals thus they play roles dan responsibilities better than before.

After that, SPI formulation and evolution will determine the process at the implementation stage. The stages of implementation consist of the process assessment, SPI roles and responsibilities, changes in organizational climate, changes in cul- ture and process culture, and pilot testing of improved processes. Several organizational conditions will support this second stage so that change processes can occur, including in terms of processes, structure, organizational climate, organizational culture, and ongoing projects. These changes are expected to be able to produce welldefined processes and structures, a conducive organizational climate, openness to innovation and change, and system development flexibility. At this SPI implementation stage, the team conducted an assessment process related to conditions where one of them had been carried out at the CMMI maturity level determination stage. After obtaining a baseline of conditions, the BLUD will determine the development to be carried out. Once defined, the BLUD designs a structured form of the roles and responsibilities of the team. Next, a bureaucratic hierarchy and an appropriate organizational culture are built. This is expected to be able to build a conducive climate during the software development process. SPI builds improved behavior, beliefs, and

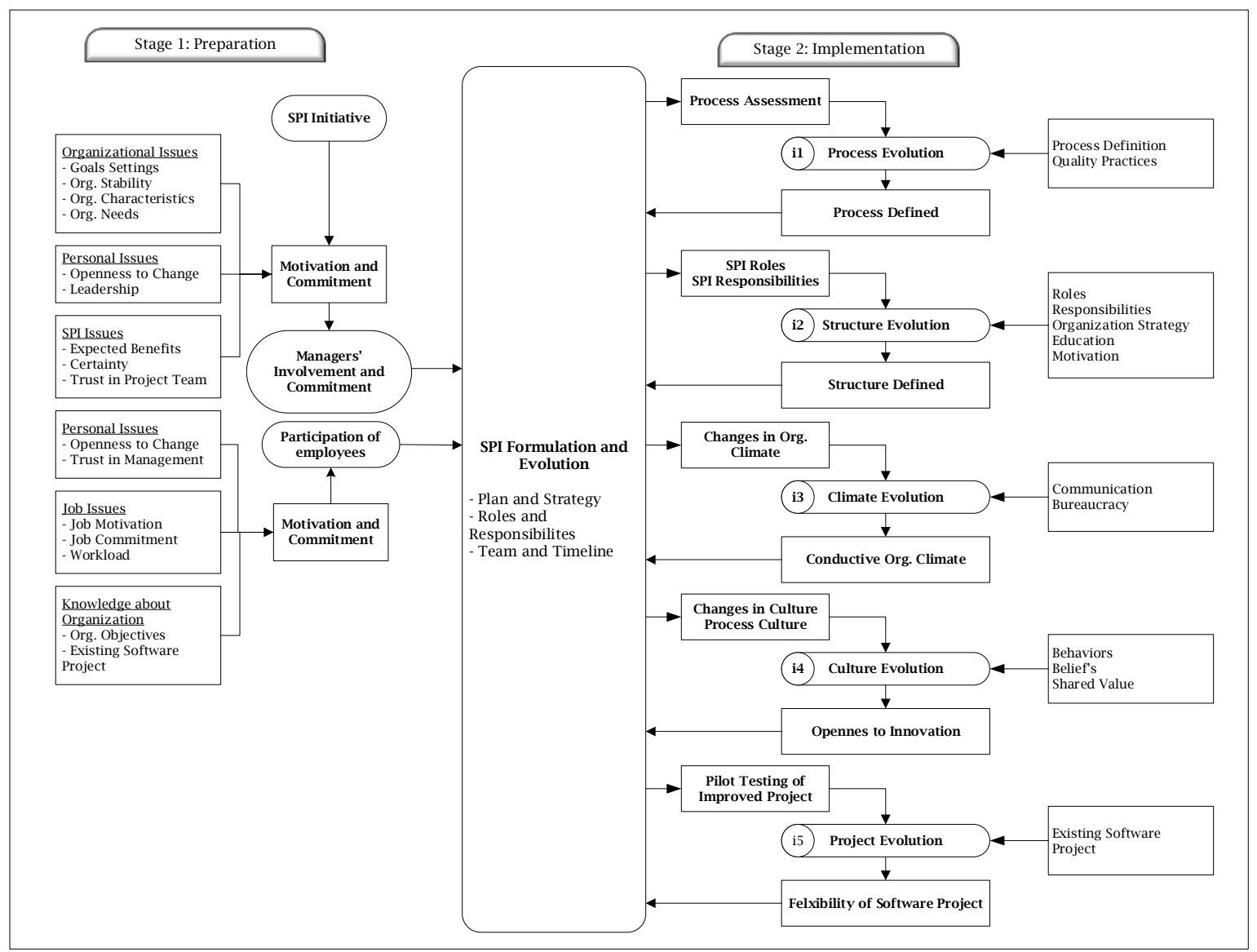

Figure 2.

Adapted Software Process Improvement 
shared value so there is an openness to innovation. After the software is ready, the next step is a pilot test. SPI builds commitment, participation, climate, and culture that is conducive to change. This will support positive changes, especially in terms of developing information systems in BLUD.

Figure 1 showed the SPI which has been adopted from Espinosa-Curiel, et al. (2016). There are several steps and factors which cannot be implemented in the bureaucracy sector. External SPI triggers cannot be predicted because BLUD is a government subordinate unit. Some organizational factors that are in the external environment cannot be touched, such as central policy, central autonomy, employee turnover mechanisms. Figure 2 shows the SPI chart that has been adjusted to the bureaucratic environment. In addition to the stages that were dropped because they were not in accordance with bureaucratic conditions, the results of this adaptation also simplified to make it easier for BLUDs to understand and run the SPI. BLUD has flexibility in infrastructure development including the development of information systems. However, this freedom still refers to policies and regulations issued by the Health Office. There are less relevant for BLUD to do, such as changes in organizational policies, management style, staff turnover mechanism, and bureaucracy.

The important stage is describing the basic architecture of the information system currently in use. When the development team does not try to understand the old system, the architectural picture will not be optimum built. Armour, et al. (1999) and Mondorf \& Wimmer (2016) stated that this design architecture cannot be implemented without knowing where the users' existing IS. This approach must be adapted to the structure of the government bureaucracy. The process of formulating public policies in a strategic scope uses a top-down approach. Information is a value-adding asset. Not only in the form of a single asset, but the entire application package is a strategic asset that should be starting at the top-level (Pulkkinen \& Hirvonen, 2005).

This policy is a step in the development of Enterprise Architecture for Public Administration. Although Lupilya (2015) stated that usually, the transformation of e-government strategic plans uses a top-down approach when applying it the approach must be reversed. The form of approach that must be used is the bottom $\Theta$ middle $\Theta$ top $\Theta$ bottom approach for the successful implementation of e-government strategic plans. The combination is used according to the Software Process Improvement (SPI) method.

Other things need to be considered, namely the BLUD connectivity dimension so that the information system can become a network platform. Patient-Centered: This concept was built to see "the box" from outside. It's about the patient's view as a customer. This method is used to capture patient expectations for services rendered as a whole. The health sector must be provided by the government as a social assurance for the society health and at the

Table 4.

Adapted Dimensions of Connected BLUD

\section{Dimensions of Connected BLUD}

$\begin{array}{ll}\text { Patient- } & \text { Patient expectations } \\ \text { Centered } & \text { Government presence } \\ \text { Assurance availability } \\ \text { structure } & \text { Technology standards } \\ & \text { Internet network } \\ & \text { Government applica- } \\ & \text { tions } \\ & \text { ICT and IT Support } \\ \text { Mollaborative } & \text { Mutually supporting } \\ \text { Operations } & \text { Shits } \\ & \text { Integrating systems } \\ & \text { Cluster-based consoli- } \\ & \text { dation } \\ & \text { BLUD ownership } \\ & \text { Business accountability } \\ \text { Public Sector } & \text { Government policies } \\ \text { Governance } & \text { and practices } \\ & \text { Regional government } \\ & \text { bureaucracy } \\ & \text { Level autonomy }\end{array}$


same time become a "business" that can increase the potential of BLUDs improvement. Besides, BLUD currently plays an important role as the first clinic to serve public health, which is provided by the government.

Current Infrastructure: This refers to the existing infrastructure used to share information and knowledge both internally and externally. BLUDs as the vanguard in public health are spread throughout the island. This high level of distribution requires internet-based applications so that when assistance is needed remote support can be done. At present, BLUD does not yet have an established system for implementing management governance and financial reporting.

Collaborative Operations: The provision of health services by the government requires collaboration between the ministries and their subordinate units. Mutually supporting units facilitated by integrated systems with databases can process big data. This requires the integration of information so that it can be the basis for decision making.
Public Sector Governance: In terms of public sector governance, BLUD as part of the government unit has the rights and obligations of the public sector entity. This governance is also related to the decentralized system of government which provides space for the development of each district/province. BLUDs are obliged to account for financial and business processes carried out. Also, they have to follow Government policies and Regional government bureaucracy.

Data architecture plays a vital role so that the database can be managed optimally. The BLUD uses several database arrangements shown in the relation. Table 5 discloses design that can be applied in ideal BLUD conditions. Activities undertaken by users in BLUD can vary both in the user's authority, job descriptions, sequences, and outputs. The design of this EA can meet the needs of BLUDs for their performance and financial reporting obligations. The user acceptance of the information technology depends on the system compatibility with the BLUD needs and also the government policies. This Enterprise Architecture model becomes a

Table 5.

Accounting information system cycle in one period

\begin{tabular}{|c|c|c|c|}
\hline Sequence & Authorized Users & System Usage & Output \\
\hline \multirow[t]{6}{*}{ Annually } & $\begin{array}{l}\text { Chief Financial } \\
\text { Officer }\end{array}$ & Business Planning & $\begin{array}{l}\text { Program Data } \\
\text { Master }\end{array}$ \\
\hline & & Activity Planning & Activity Data Master \\
\hline & & $\begin{array}{l}\text { Business and Budget } \\
\text { Planning }\end{array}$ & $\begin{array}{l}\text { Business and Budget } \\
\text { Planning Report }\end{array}$ \\
\hline & Accounting Staff & $\begin{array}{l}\text { Budget Planning } \\
\text { Account Set-Up }\end{array}$ & $\begin{array}{l}\text { Budget Data Master } \\
\text { Account Data Master }\end{array}$ \\
\hline & & Reporting Menu & Financial Report \\
\hline & & $\begin{array}{l}\text { Business and Budget } \\
\text { Planning }\end{array}$ & $\begin{array}{l}\text { Business and Budget } \\
\text { Realization }\end{array}$ \\
\hline Semi-Annually & $\begin{array}{l}\text { Chief Financial } \\
\text { Officer }\end{array}$ & $\begin{array}{l}\text { Business and Budget } \\
\text { Evaluation }\end{array}$ & $\begin{array}{l}\text { Business and Budget } \\
\text { Amendment }\end{array}$ \\
\hline \multirow[t]{3}{*}{ Monthly } & $\begin{array}{l}\text { Income Treasurer } \\
\text { Staff }\end{array}$ & $\begin{array}{l}\text { Inflow Cash } \\
\text { Transaction }\end{array}$ & Inflow Cash Report \\
\hline & Expenditure Staff & $\begin{array}{l}\text { Outflow Cash } \\
\text { Transaction }\end{array}$ & Outflow Cash Report \\
\hline & Accounting Staff & $\begin{array}{l}\text { Depreciation } \\
\text { Recognition }\end{array}$ & Depreciation Journal \\
\hline Daily & $\begin{array}{l}\text { Income Treasurer } \\
\text { Staff } \\
\text { Expenditure Staff }\end{array}$ & $\begin{array}{l}\text { Inflow Cash } \\
\text { Transaction } \\
\text { Outflow Cash } \\
\text { Transaction }\end{array}$ & $\begin{array}{l}\text { Receipt of Cash/ } \\
\text { Invoice } \\
\text { Receipt of } \\
\text { Disbursement Cash/ } \\
\text { Bill }\end{array}$ \\
\hline
\end{tabular}


bridge between the organization's goals and technology information to meet those requirements.

\section{CONCLUSION}

Enterprise Architecture (EA) is a guide to developing organizations dynamically. The EA framework is formed by methods to identify gaps between the strategy and its objectives and information systems. In addition, EA is also able to handle complexity and agility in public organizations. Organizations that understand the condition of its maturity level. This position will facilitate the organization when identifying and assessing the current process. The right baseline can be a strong basis for determining the development carried out. Then, the organization is able to increase the motivation and commitment of personnel to increase the success of the Software Process Improvement (SPI). This guide will make it easier for users to understand the stages in software development with the SPI approach.

\section{LIMITATIONS AND SUGGESTIONS}

The architecture model has been presented, we plan to continue our research in two activities: 1) Developing the web-software based on our blueprint for Regional Public Service Agency. 2) Implementing a bottom-up approach for evaluating the model of web-software with real data.

Finally, this research has several limitations. The next studies can measure the external SPI triggers to better know the success IS in governmental sectors. Thereafter, in case this model is suitable, it will be a pilot project for other Regional Public Service Agencies in Indonesia. This software can be developed in several upgrade levels, including the financial report converter version of Government Accounting Standards to Financial Accounting Standards (private) so that the BLUD can assess the extent of profitability obtained by using the accrual method, consolidation at the DinKes level so that consolidation is not needed anymore manual, as well as development for other software that can be used by BLUD nonhealth sector. This study makes guidelines for management, planners, and systems analysts at BLUD so that technical matters are not discussed in depth. Further research can be complemented by using Entity-Relationship Diagrams (ERD) that can describe the rules and associations between objects or entities.

\section{REFERENCES}

Anthopoulos, L.G., Gerogiannis, V., \& Fitsilis, P. (2010). Enterprise Architecture for e-Strategy Standardization and Management: Lessons Learnt from Greece. International Journal of Digital Society, 1(4), 289-297.

Armour, F.J., Kaisler, S.H., \& Liu, S.Y. (1999). Building An Enterprise Architecture Step by Step. IT Professional, August.

Bibi, S., Stamelos, I., Gerolimos, G., \& Kollias, V. (2010). BBN Based Approach for Improving The Software Development Process of An SME - A Case Study. Journal of Software Maintenance and Evolution: Research and Practice, 22(May 2009), 121-140.

Brynjolfsson, E., \& Hitt, L. M. (1998). Beyond the Productivity Paradox. Communications of the ACM, 41(8), 49-55.

Bueno, S., \& Gallego, M. D. (2017). Managing Top Management Support in Complex Information Systems Projects: An End -user Empirical Study. Journal of Systems and Information Technology, 19(1-2), 151-164.

Chew, E. K., \& Gh Dehbokry, S. (2014). The Strategic Requirements for an Enterprise Business Architecture Framework by SMEs. Lecture Notes on Information Theory.

CMMI Institute. (2003). CMMI Levels of Capability and Performance. In cmmiinstitute.com.

Dos, B. L., Peffers, K., Science, S. O., Jun, N. M., Dos, B. L., \& Ken, S. (2017). Rewards to Investors in Innovative Information Technology Applications: First Movers and Early Followers in ATMs. Original Science, 6(3), 241-259.

Eldenburg, L., Soderstrom, N., Willis, V., \& $\mathrm{Wu}$, A. (2010). Behavioral changes following the collaborative development of an accounting information system. Accounting, Organizations and Society, 35(2), 222- 
237.

Espinosa-curiel, I. E., \& Rodríguez-jacobo, J. (2016). Understanding SPI in Small Organizations: A Study of Mexican Software Enterprises. Journal of Software: Evolution and Process, 28, 372-390.

Fajri, F. A., \& Oktyawati, D. (2018). Peran Affection Attachment, Perceived Cost, Dan Continuance Sebagai Faktor Moderasi Pengukuran Pemanfaatan Sistem Informasi Terhadap Kinerja dan Akuntabilitas Publik (Studi Kasus di Pemerintah Daerah DIY). Jurnal AKSI, 3(2), 112-121.

Goldenson, D. R., Herbsleb, J. D., Goldenson, D. R., \& Herbsleb, J. D. (1995). After the Apraisal: A Systematic Survey of Process Improvement, Its Benefits, and Factors that Influence Success (Issue August). Pennsylvania: Software Engineering Institute.

Hameed, A., Counsell, S., \& Swift, S. (2012). A conceptual model for the process of IT innovation adoption in organizations. Journal of Engineering and Technology Management, 29(3) 358-390.

Hanseth, O., \& Lyytinen, K. (2010). Design Theory for Dynamic Complexity in Information Infrastructures: The Case of Building Internet. Journal of Information Technology, 25(1), 1-19.

Hossain, M. A., \& Quaddus, M. (2012). Expectation-Confirmation Theory in Information System Research: A Review and Analysis. In Information Systems Theory, 441-469. Springer.

Hwang, I., \& Cha, O. (2018). Examining technostress creators and role stress as potential threats to employees' information security compliance. Computers in Human Behavior, 81, 282-293.

Ii, V. J. S., John, S., York, N., \& States, U. (2019). An Examination of the LongTerm Business Value of Investments in Information Technology. Information Systems Frontiers, 21(1), $1-28$.

Iyamu, T. (2011). The Architecture of Information in Organisations. $S A$ Journal of Information Management, 13(1), 1-9.

Iyamu, T. (2018). Implementation of the enterprise architecture through the Zachman Framework. Journal of Systems and Information Technology, 20(1), 2-18.

Kang, D., Lee, J., \& Kim, K. (2010).
Alignment of Business Enterprise

Architectures using fact-based ontologies. Expert Systems with Applications, 37(4), 3274-3283.

Kaul, M., Storey, V. C., \& Woo, C. (2017). Domain Design Principles for Managing Complexity in Conceptual Modeling. Research in Progress Proceedings of the 12th International Conference on Design Science Research in Information Systems and Technology. Karlsruhe, Germany. 30 May - 1 Jun. Karslruhe: Karlsruher Institut für Technologie (KIT), 1-10.

Kaushik, A., \& Raman, A. (2014). Data Driven Outcome-Based Healthcare Initiatives: Learnings From Public Sector in India. 14th European Conference on EGovernment, June, 144-152.

Lapalme, J., Gerber, A., Van Der Merwe, A., Zachman, J., Vries, M. De, \& Hinkelmann, K. (2016). Exploring The Future of Enterprise Architecture: A Zachman Perspective. Computers in Industry, 79, 103-113.

Lupilya, E. C. (2015). E-government Strategic Plan Implementation in Tanzania: Learning from Challenges and Experiences from Kenya, Korea, India and Malaysia. The Korean Journal of Policy Studies, 30(2), 147175.

M. Valle, A., A.P. Santos, E., \& R. Loures, E. (2017). Applying Process Mining Techniques in Software Process Appraisals. Information and Software Technology, 87, 19-31.

Mondorf, A., \& Wimmer, M. A. (2016). Requirements for an architecture framework for Pan-European Egovernment services. Lecture Notes in Computer Science (Including Subseries Lecture Notes in Artificial Intelligence and Lecture Notes in Bioinformatics), 9820 LNCS, 135-150.

Niazi, M., Wilson, D., \& Zowghi, D. (2005). A Maturity Model for The Implementation of Software Process Improvement: An Empirical Study. Journal of Systems and Software, 74(2 SPEC. ISS.), 155-172.

Pulkkinen, M., \& Hirvonen, A. (2005). EA Planning, Development and Management Process for Agile Enterprise Development. The ThirtyEighth Annual Hawaii International Conference on System Sciences, 223.

Peraturan Menteri Dalam Negeri Nomor 79 Tahun 2018 tentang Badan Layanan Umum Daerah, (2018). 
Peraturan Menteri Kesehatan Republik Indonesia Nomor 31 Tahun 2019 Tentang Sistem Informasi Puskesmas, (2019).

Saha, P. (2010). Enterprise Architecture As Platform: Advancing the Whole - of Government Enterprise Architecture Adoption with Strategic (Systems) Thinking. NUS Institute of Systems Science.

SEI. (2002). Capability Maturity Model $^{\circledast}$ Integration (CMMISM).

Sessions, R. (2015). A Comparison of the Top Four Enterprise-Architecture Methodologies. ObjectWatch.Inc, 2007.

Sharma, R., \& Yetton, P. (2007). The Contingent Effects of Training, Technical Complexity, and Task Interdependence on Successful Information Systems Implementation. MIS Quarterly: Management Information Systems, 31(2), 219-238.

Singh, A., \& Abraham, A. (2008). Neuro Linguistic Programming: A Key to
Business Excellence. Total Quality Management, 19, 141-149.

Tamm, T., Seddon, P.B., Shanks, G., \& Reynolds, P. (2011). Delivering Business Value Through Enterprise Architecture. Journal of Enterprise Architecture, May, 1-15.

Tian, F., \& Xu, S.X. (2015). How Do Enterprise Resource Planning Systems Affect Firm Risk? Post Implementation Impact. MIS Quarterly, 39(1), 39-60.

Utomo, A.P. (2014). Pemodelan Arsitektur Enterprise Sistem Informasi Akademik Pada Perguruan Tinggi Menggunakan Enterprise Architecture Planning. Jurnal Simetris, 5(1), 33-40.

Whittle, R. (2016). Enterprise Business Architecture. In CRC Press (Issue 1).

Zachman, J.A. (2016). The Framework for Enterprise Architecture: Background, Description and Utility. Zachman International Enterprise Architecture. https://www.zachman.com. 